\title{
KEBIJAKAN LINGKUNGAN HIDUP DALAM KONTEKS GOOD GOVERNANCE
}

\author{
Oleh : \\ Yasminingrum \\ Dosen Fakultas Hukum Univ 17 Agustus 1945 Semarang \\ Mahasiswa Program Doktor Ilmu Hukum Fakultas Hukum UNTAG Semarang \\ Email: rudi241260@gmail.com
}

\begin{abstract}
Abstrak
Kebijakan lingkungan hidup harus dijalankan tanpa ada kompromi antara aktor pemegang kebijakan dengan masyarakat industriawan maupun masyarakat umum. Kenyataannya seringkali kebijakan lingkungan hidup tidak sejalan dengan konsteks good governance yang mengarahkan pada prinsip partisipasi, penegakan hukum, transparasni, daya tanggap, consensus orientation, keadilan, effectiveness and efficiency, akuntabilitas dan visi strategis, oleh karena itu kebijakan lingkungan hidup selalu mempertimbangkan setiap aktivitas yang memanfaatkan sumber daya alam dan lingkungan agar tercapai tujuan perlindungan hukum dan pengelolaan lingkungan hidup yang sesuai dengan konsteks good gonernance.
\end{abstract}

Kata Kunci: kebijakan, Lingkungan Hidup, Good Governance.

\section{ENVIRONMENTAL POLICY IN CONTEXT OF GOOD GOVERNANCE}

BY

Yasminingrum

Lecturer of Faculty of Law Univ August 17, 1945 Semarang Student of Doctoral Program of Law Faculty of Law, UNTAG Semarang Email: rudi241260@gmail.com

\begin{abstract}
The environmental policy must be implemented without any compromise between the policy-holding actors and the industrialist society as well as the general public. The fact is that environmental policies are often not in line with good governance constants that lead to the principles of participation, law enforcement, transparency, responsiveness, consensus orientation, equity, effectiveness and efficiency, accountability and strategic vision, therefore environmental policies always consider every activity utilizing natural resources and the environment in order to achieve the objectives of legal protection and environmental management in accordance with context good governance.
\end{abstract}

Keywords: Policy, Environment, Good Governance. 


\section{A.Latar Belakang Masalah}

Krisis lingkungan hidup merupakan tantangan yang sangat besar pada abad ini. Tantangan ini didapati terutama di negaranegara yang sedang membangun, karena adanya berbagai aktivitas pembangunan yang bertujuan meningkatkan kesejahteraan umat manusia yang sering pula membawa dampak terhadap perubahan lingkungan.

Aktivitas pembangunan yang tidak disertai dengan pengawasan dan pengelolaan lingkungan hidup yang baik mengakibatkan malapetaka pada umat manusia. Dengan demikian konsep pengawasan, pengelolaan dan pelaksanaan undang-undang lingkungan hidup merupakan kunci utama terhadap pencapaian kelestarian lingkungan. Sebagaimana dikatakan oleh Samodra Wibowo, bahwa kelestarian tetap tersedianya sumber daya alam bagi aktivitas kehidupan kita $^{1}$

Perkembangan ilmu pengetahuan, teknologi dan industri yang cepat pada saat ini tentu sangat dirasakan pengaruhnya, baik dampak positif maupun dampak negatif dan dampak negatif ini harus diwaspadai agar tidak menjadi malapetaka bagi kehidupan masa kini maupun masa yang akan datang.

Masalah-masalah lingkungan hidup dapat menjadi bencana yang dapat mempengaruhi kualitas kehidupan manusia. Tanda-tanda masalah lingkungan hidup seperti : ${ }^{2}$ adanya polusi, pemanasan global, fotokimia kabut, hujan asam,erosi, banjir, intrusi/pengikisan dan sebagainya, telah mulai kelihatan sejak pertengahan abad ke 20. Pada era globalisasi ini, liputan media massa dapat memberikan informasi yang sangat cepat tentang kejadian-kejadian kerusakan lingkungan yang disebabkan oleh pengelolaan lingkungan yang kurang tepat.

\footnotetext{
1 Samodra Wibowo, Reformasi Administrasi, Bunga Rampai Pemikiran Administrasi Negara/Publik, Gava Media, Jogjakarta, 2005, hal 127.

2 WALHI, Laporan Kegitan WALHI Tahun 1995-2000, 2001
}

Akibat pengelolaan yang tidak benar dan akibat pencemaran lingkungan, diperkirakan dalam masa 300 tahun belakangan ini telah banyak species yang sudah punah dari bumi, dan semakin lama akan semakin bertambah, sehingga suatu saat manusia juga akan dapat menjadi korban kepunahan. ${ }^{3}$ Dalam proses pembangunan, kehadiran undang-undang dan peraturan tentang lingkungan hidup erat kaitannya dengan kualitas fisik dan nilai ekologi suatu kawasan. ${ }^{4}$

Sumber daya alam yang kita miliki merupakan karunia dari Tuhan Yang Maha Esa, maka sebagai bangsa Indonesia wajib mengelola, memanfaatkan dan memelihara sumber daya alam untuk memajukan kesejahteraan umum sebagaimana diamanatkan oleh Undang Undang Dasar 1945 dan untuk mencapai kebahagiaan hidup berdasarkan Pancasila. Untuk itu guna menunjang kesejahteraan perlu melaksanakan pembangunan yang berwawasan lingkungan yang berdasarkan kepada kebijakan nasional yang terpadu dan menyeluruh dengan memperhitungkan kebutuhan generasi kini dan masa depan.

Hal ini supaya pengelolaan lingkungan hidup tetap menjadi sumber dan penunjang bagi rakyat dan bangsa Indonesia serta mahkluk hidup lainnya demi kelangsungan hidup dan peningkatan kualitas hidup itu sendiri Pengelolaan lingkungan dan pelestarian lingkungan merupakan tanggungjawab kita bersama, pemerintah harus selalu menumbuhkembangkan kesadaran masyarakat akan pentingnya lingkungan hidup yang baik dan sehat sebagai bagian dari hak azasi manusia.

Disamping itu dalam pengelolaan dan pelestarian lingkungan hidup peran serta masyarakat, baik perorangan maupun

\footnotetext{
3 Usman R, Pokok Pokok Hukum Alam Sekitar Nasional, Akademika Pressindo, Jakarta, 1993, hal 16

4 Djanius Djamin, Pengawasan Dan Pelaksanaan Undang Undang Lingkungan Hidup, Suatu Analisis Sosial, Yayasan Obor Indonesia, Jakarta, 2007, hal 15
} 
lembaga swadaya masyarakat juga harus ikut berperan serta. Dengan demikian harus ada kerjasama antara pihak pemerintah, pihak industri dan masyarakat.

Negara Indonesia telah memiliki sarana hukum yang berkaitan dengan pengelolaan lingkungan hidup yaitu Undang Undang Nomor 32 Tahun 2009 Tentang Perlindungan Dan Pengelolaan Lingkungan Hidup. Dalam Undang Undang No. 32 Tahun 2009 tersebut disebutkan bahwa ciri dari pengelolaan lingkungan hidup adalah keterpaduan.

Kelembagaan yang ada yang mengurusi masalah lingkungan hidup ada di tingkat pusat, tingkat sektoral dan tingkat daerah. Pelimpahan kewenangan dari pusat kepada daerah berdasarkan pada asas desentralisasi, dekonsentrasi dan asas tugas pembantuan. Dalam melaksanakan aktivitas pembangunan tentunya juga akan berpadu dengan aktivitas masyarakat yang memiliki dinamika sosial budaya, ekonomi, politik, dan berbagai permasalahan lingkungan hidup yang seimbang, maka kebijakan pembangunan harus senantiasa didasari oleh pertimbangan yang matang antara aspek ekonomi, politik, sosial budaya dan lingkungan hidup.

Namun demikian, pada hakikatnya aspek lingkungan sering diabaikan sehingga dapat mengakibatkan konflik sosial dan krisis lingkungan. Meskipun kompleksitas permasalahan lingkungan hidup belum menunjukkan terjadinya krisis lingkungan, maka untuk menjaga kondisi lingkungan tetap serasi, tindakan pengawasan, pengelolaan dan pelaksanaan undangundang lingkungan hidup merupakan hal yang sangat penting untuk diperhatikan.

Oleh karena itu kebijakan lingkungan yang berupa peraturan dalam implementasinya mewujudkan good governance harus diusahakan agar tidak merusak tata lingkungan hidup manusia. Dan kebijakan lingkungan hidup harus pula mempertimbangkan kebutuhan generasi yang akan datang dengan tidak memberikan toleransi yang diberikan kepada pelaku yang menjadi alasan untuk tidak mematuhi kebijakan.

\section{B. Permasalahan}

Untuk mewujudkan pembangunan berkelanjutan, maka implementasi prinsip good governance menjadi tuntutan dalam menerapkan kebijakan lingkungan hidup. Untuk itu akan dibahas tentang bagaimana kebijakan lingkungan hidup dalam konteks good governance.

\section{Pembahasan}

Undang Undang Dasar Negara Republik Indonesia Tahun 1945 di dalam Pasal 33 ayat (3) memberi petunjuk bahwa bumi, air, dan kekayaan alam yang terkandung didalamnya adalah pokok-pokok kemakmuran rakyat, sehingga harus dikuasai negara untuk digunakan sebesar-besarnya kemakmuran rakyat. Arah pembangunan jangka panjang tertuju pada pembangunan manusia Indonesia seutuhnya dan pembangunan seluruh masyarakat Indonesia.

Untuk meningkatkan kemakmuran rakyat perlu dilaksanakan pembangunan secara berencana karena kegiatan-kegiatan pembangunan merupakan aktivitas yang merubah lingkungan yaitu dapat mempengaruhi struktur dasar ekosistem yang berupa terganggunya keseimbangan antara komponen-komponen ekosistem dan berupa pencemaran yang menimbulkan kerusakan bagi berfungsinya proses-proses alam dalam ekosistem. Kerusakan tersebut dapat menimbulkan gangguan terhadap kelangsungan hidup manusia.

Resiko yang ditimbulkan oleh pembangunan dapat berupa :

a. rusaknya berbagai sistem pendukung perikehidupan yang vital bagi manusia, baik sistem biofisik maupun sosial;

b. munculnya bahaya-bahaya baru 
akibat ciptaan manusia, seperti bahan berbahaya dan beracun dan hasil-hasil bioteknologi;

c. pengalihan beban resiko kepada generasi berikutnya atau kepada daerah lain, dan;

d. kurang berfungsinya sistem organisasi sosial dalam masyarakat. ${ }^{54}$

Menyadari akan hal tersebut, maka pemerintah mengusahakan untuk dapat mengurangi dan menghindarkan resiko yang diakibatkan oleh pembangunan dengan menerapkan peraturan-peraturan yang berkaitan dengan lingkungan hidup. Salah satu kebijakan tersebut adalah Undang Undang No. 32 Tahun 2009 Tentang Perlindungan Dan Pengelolaan Lingkungan Hidup.

Pengertian lingkungan hidup secara yuridis digariskan dalam pasal 1 angka 1 Undang Undang No. 32 Tahun 2009 yang berbunyi "lingkungan hidup adalah kesatuan ruang dengan semua benda, daya, keadaan, dan makhluk hidup, termasuk manusia dan perilakunya, yang mempengaruhi alam itu sendiri, kelangsungan perikehidupan dan kesejahteraan manusia serta makhluk hidup lainnya"

Dari pengertian tersebut, lingkungan hidup manusia itu dapat digolongkan atas :

a. Lingkungan fisik, adalah segala sesuatu di sekitar kita yang berbentuk benda mati seperti rumah, kendaraan, gunung, udara, sinar matahari dan lain yang semacamnya.

b. Lingkungan biologis, adalah segala sesuatu yang berada disekitar manusia yang berupa organisme hidup lainnya selain dari manusia sendiri, binatang, tumbuhtumbuhan, jasad renik (plankton)

\footnotetext{
$5 \quad{ }^{4}$ Harun M Husein, Lingkungan Hidup Masalah Pengelolaan Dan Penegakkan Hukumnya, Sinar Grafika, Jakarta, hal 108.
}

dan lain-lain.

c. Lingkungan sosial, adalah manusia lain yang berada disekitarnya seperti tetangga, teman dan lain-lain. ${ }^{6}$

Pembangunan yang kita lakukan seringkali dapat menimbulkan suatu malapetaka, hal ini karena dengan melaksanakan pembangunan berarti melakukan aktivitas yang merubah lingkungan. Perubahan yang dihasilkan oleh pembangunan sebagian telah direncenakan dan sebagian lagi di luar perencenaan. Perubahan yang tidak terencana kita sebut dengan efek sampingan atau dampak. Dan dampak yang dihasilkan dari suatu pembangunan ada yang bersifat positif dan ada yang bersifat negatif karena terjadi perubahan yang mendasar terhdap ekosistem.

Dampak lingkungan akan mempengaruhi kehidupan manusia, sosial budaya, sosial ekonomi, flora dan fauna. Hal tersebut mengakibatkan :

a. gangguan kesehatan pada manusia/ masyarakat;

b. terjadinya perubahan manusia dan masyarakat yang diakibatkan oleh aktivitas pembangunan;

c. banyak tumbuhan dan hewan yang mati.

Yang dimaksud dengan dampak lingkungan hidup menurut pasal 1 angka 26 UU No. 32 Tahun 2009 Tentang Perlindungan dan Pengelolaan Lingkungan Hidup, adalah pengaruh perubahan pada lingkungan hidup yang diakibatkan oleh suatu usaha dan/ atau kegiatan. Dalam kaitannya dengan dampak lingkungan perlu diperhatikan mengenai daya dukung lingkungan. Yang dimaksud dengan daya dukung lingkungan hidup menurut pasal 1 angka 7 UU No. 32 Tahun 2009 tersebut adalah kemampuan lingkungan hidup untuk mendukung

\footnotetext{
6 Fuad Amsyari, Prinsip-Prinsip Masalah Pencemaran Lingkungan, Ghalia Indonesia, Jakarta, Hal 11-12 $7 \quad$ Ibid
} 
perikehidupan manusia dan makhluk hidup lain dan keseimbangan antara keduanya.

Bahaya yang senantiasa mengancam kelestarian lingkungan adalah pencemaran dan perusakan lingkungan. Masalah pencemaran timbul bilamana suatu zat atau energi dengan tingkat konsentrasi yang sedemikian rupa hingga dapat mengubah kondisi lingkungan, baik langsung atau tidak langsung, dan pada akhirnya lingkungan tidak berfungsi sebagaimana mestinya.

$$
\text { Pencemaran lingkungan }
$$

menimbulkan kerugian dalam bentuk :

a. kerugian ekonomi dan sosial (economic \& social injury) dan;

b. gangguan sanitary (sanitary hazard). ${ }^{8}$ Pencemaran lingkungan hidup sebagaimana tertulis dalam pasal 1 angka 14 UU No. 32 Tahun 2009 Tentang Perlindungan Dan Pengelolaan Lingkungan Hidup adalah masuk atau dimasukkannya makhluk hidup, zat, energi, dan/atau komponen lain ke dalam lingkungan hidup oleh kegiatan manusia sehingga melampui baku mutu lingkungan hidup yang telah ditetapkan.

Sedangkan perusakan lingkungan hidup sebagaimana dalam pasal 1 angka 16 UU No. 32 Tahun 2009 Tentang Perlindungan dan Pengelolaan Lingkungan Hidup, adalah tindakan orang yang menimbulkan perubahan langsung atau tidak langsung terhadap sifat fisik dan/atau hayati lingkungan hidup sehingga melampui criteria baku kerusakan lingkungan hidup. .

Dalam ketentuan pasal 1 angka 2 UU No. 32 Tahun 2009 Tentang Perlindungan Dan Pengelolaan Lingkungan Hidup dikatakan bahwa perlindungan dan pengelolaan lingkungan hidup adalah upaya sistematis dan terpadu yang dilakukan untuk melestarikan fungsi lingkungan hidup dan mencegah terjadinya pencemaran dan/atau

8 RM Sutamihardja, Kualitas Dan Pencemaran Lingkungan, IPB, Bogor, 1978, hal 3 kerusakan lingkungan hidup yang meliputi yang meliputi perencanaa, pemanfaatan, pengendalian, pemeliharaan, pengawasan, dan penegakan hukum.

Dengan demikian pengelolaan lingkungan hidup mempunyai ruang lingkup

a. pengelolaan secara rutin;

b. perencanaan dini pengelolaan lingkungan hidup suatu daerah yang menjadi dasar dan tuntutan bagi perencanaan pembangunan;

c. perencanaan pengelolaan lingkungan hidup untuk memperbaiki lingkungan yang mengalami kerusakan baik karena sebab alamiah maupun karena tindakan manusia.

Untuk pencegahan dan penanggulangan terhadap lingkungan yang dimaksud dalam pengelolaan lingkungan meliputi :

1. Peningkatan kesadaran lingkungan diantara karyawan dan pengusaha khususnya masyarakat umumnya tentang akibat buruk suatu pencemaran.

2. Pembentukan organisasi penanggulanagan pencemaran untuk mengadakan monitoring berkala guna mengumpulkan selengkap mungkin.

3. Penanganan kriteria tentang kualitas dalam peraturan perundang-undangan.

4. Penentuan daerah industri yang berencana dengan baik dikaitkan dengan planologi kota, pedesaan, dalam memperhitungkan berbagai segi.

5. Penyempurnaan alat produksi melalui kemajuan produksi sehingga bahanbahan pencemaran pada proses produksi dapat dikurangi. ${ }^{9}$

Adapun tujuan dari perlindungan dan pengelolaan lingkungan hidup terdapat dalam pasal 3 Undang Undang No. 32 Tahun 2009 Tentang Perlindungan Dan Pengelolaan

9 Otto Sumarwoto, Ekologi Lingkungan Hidup Dan Pembangunan, Djambatan, Jakarta, 1989, hal 66 
Lingkungan Hidup adalah :

a. Melindungi wilayah Negara Kesatuan Republik Indonesia dari pencemaran dan/atau kerusakan lingkungan hidup;

b. Menjamin keselamatan, kesehatan, dan kehidupan manusia;

c. Menjamin kelangsungan kehidupan makhluk hidup dan kelestarian ekosistem;

d. Menjaga kelestarian fungsi lingkungan hidup;

e. mencapai keserasian, keselarasan dan keseimbangan lingkungan hidup;

f. Menjaminnya terpenuhinya keadilan generasi masa kini dan generasi masa depan;

g. Menjamin pemenuhan dan perlindungan hak atas lingkungan hidup sebagai bagian dari hak asasi manusia;

h. Mengendalinya pemanfaatan sumber daya secara bijaksana;

i. Mewujudkan pembangunan berkelanjutan;

j. Mengantisipasi isu lingkungan global.

Menurur Heinz Eulu \& Kenneth

Prewitt, dalam bukunya "Lbryrinths of Democracy, 1973", mengatakan bahwa kebijakan publik adalah "Keputusan Tetap" yang dicirikan dengan konsistensi dan pengulangan (repitisi) tingkah laku dari mereka yang membuat dan dari mereka yang mematuhi keputusan tersebut. ${ }^{10}$ Menurut Thomas R Dye, dalam bukunya "Understanding Public Policy, 1976", menyatakan bahwa kebijakan publik adalah apa yang dipilih oleh pemerintah untuk dilakukan dan tidak dilakukan. ${ }^{11}$

Kebijakan lingkungan hidup adalah produk yang dihasilkan dan dikelola oleh pemerintah. Dengan semakin meningkatnya kesadaran masyarkat akan hak dan kewajiban atas lingkungan hidup yang baik dan sehat yang merupakan bagian dari hak azasi manusia, maka perlindungan dan pengelolaan lingkungan hidup menjadi suatu kewajiban yang harus dilakukan oleh pemerintah.

Good governance sebagai suatu penyelenggaraan manajemen pemerintahan yang solid dan bertanggungjawab yang sejalan dengan prinsip demokrasi, efisien dan pemerintahan yang bebas dan bersih dari kegiatan korupsi, kolusi, dan nepotisme. Good governance menjamin adanya proses kesejajaran, kesamaan dan keseimbangan peran serta, saling mengontrol yang dilakukan oleh pemerintahan, masyarakat, dan industriawan.

UNDP merumuskan karakteristik pemerintahan yang baik (good governance), meliputi partisipasi, penegakan hukum, transparansi, daya tanggap, consensus orientation, keadilan, effectiveness and efficiency, akuntabilitas. ${ }^{12}$

Untuk itu, pemerintah dituntut untuk lebih kreatif, inovatif dan cerdas dalam melaksanakan kebijakan lingkungan hidup yang merupakan bagian dari hak azasi manusia untuk mendapatkan lingkungan yang bersih dan sehat. Di dalam konteks good governance, pemerintah harus dapat memprioritaskan mana yang harus dilakukan dan dapat membedakan mana yang urgen dan tidak perlu dilakukan dengan mempertimbangkan sumber daya alam.

Kebijakan lingkungan hidup tidak boleh lemah dalam implementasinya sehingga tidak harus ada toleransi untuk tidak mematuhi kebijkan lingkungan hidup tersebut. Dalam rangka mewujudkan good governance, pemerintah tidak boleh ragu dalam memberikan hukuman yang semestinya kepada warga masyarakat yang tidak berperilaku sesuai kebijakan

Sidu Wasistiono, Kapita Selekta Penyelenggaraan Pemerintahan Daerah, Fokusmedia, Bandung, 2003, hal 33-35 
lingkungan hidup.

\section{Analisis Mengenai Dampak}

Linkungan Hidup sebagai salah satu proses dari perizinan lingkungan merupakan dokumen aktivitas dan penilaian yang harus dipertanggungjawabkan secara ilmiah. Tidak dibenarkan bila ada kompromi antara industriawan dengan pejabat penanggungjawab kebijakan dalam menanangani kasus lingkungan.

Proses penilaian analisis mengenai dampak lingkungan merupakan satu kesatuan dengan proses permohonan dan penerbitan izin lingkungan. Dengan adanya analisis mengenai dampak lingkungan dalam proses perencanaan usaha dan/atau kegiatan, maka pejabat yang bertanggungjawab atas kebijakan lingkungan sesuai dengan kewenangannya mendapatkan informasi yang luas dan mendalam terkait dengan dampak lingkungan yang mungkin akan terjadi dari suatu usaha dan/atau kegiatan tersebut dan langkah-langkah pengendaliannya, baik dari aspek teknologi, sosial dan kelembagaan.

Dengan diterapkannya prinsip keberlanjutan dan berwawasan lingkungan dalam proses pelaksanaan kebijakan pembangunan dan lingkungan hidup dalam konsteks good governance, maka persoalan lingkungan hidup terletak pada faktor perilaku dari aktor dalam mengoperasionalkan kebijakan demi terlindunginya lingkungan hidup dan perilaku industriawan dan masyarakat yang sesuai dengan kebijakan lingkungan hidup.

Sebagaimana dikatakan oleh Sonny Keraf, bahwa sejatinya pembangunan berkelanjutan adalah sebuah etika politik yang mengarahkan perilaku kita tentang bagaimana pembangunan itu seharusnya dijalankan. ${ }^{13}$ Oleh Satjipto rahardjo, pemaknaan demikian memerlukan determinasi moral yang menempatkan

13 Sonny Keraf, Etika Lingkungan, Buku Kompas, Jakarta, 2002, hal 167. manusia sebagai bagian dari alam semesta, buka di atas atau terpisah dari alam. Manusia adalah insan yang seharusnya selalu merasa saling memiliki, saling terhubung, dan saling menyayangi dengan kosmos secara keseluruhan. ${ }^{14}$

Kebijakan lingkungan hidup dalam konteks good governance akan mewujudkan perlindungan dan pengelolaan lingkungan yang selalu mempertimbangkan setiap aktivitas jika hendak memanfaatkan sumber daya alam dan lingkungan hidup dalam memenuhi kebutuhan kita. Untuk itu tujuan perlindungan dan pengelolan lingkungan hidup secara mendasar berada pada wilayah cara berhukum, sehingga pejabat kebijakan yang bertanggungjawab atas lingkungan hidup dapat memaknai, memahami dan menjalankan hukum

\section{Penutup}

Kebijakan lingkungan hidup dalam konteks good governance dilaksanakan melalui tindakan pejabat selaku penanggungjawab kebijakan, industriawan dan masyarakat berlandaskan pada etika dan moral. Tidak berlandaskan pada kompromi yang mengakibatkan tidak mematuhi kebijakan tersebut.

Pejabat selaku penanggungjawab kebijakan lingkungan hidup demi tercapainya kelestraian lingkungan diselenggarakan dengan transparan, responsif, partisipatif, taat pada ketentuan hukum, berorientasi pada konsensus, adanya kebersamaan, akuntabilitas dan memiliki visi yang strategis.

\section{DAFTAR PUSTAKA}

\section{Djanius Djamin, Pengawasan Dan}

\footnotetext{
14 Satjipto rahardjo, Membedah Hukum Progresif, Editor
} Joni Emirzon et al, Buku Kompas, Jakarta, 2006, hal 6 
Pelaksanaan Undang Undang Lingkungan Hidup, Suatu analisis, Yayasan Obor Indonesia, Jakarta, 2007

Fuad Amsari, Prinsip Prinsip Masalah Pencemaran Lingkungan, Ghalia Indonesia, Jakarta

Husein M harun, Lingkungan Hidup Masalah Pengelolaan Dan Penegakan Hukumnya, Sinar Grafika, Jakarta

Kristian Widya Wicaksono, Administrasi Dan Birokrasi Pemerintah, graham Ilmu, Jogjakarta, 2006

RM Sutamihardja, Kualitas Dan Pencemaran Lingkungan, IPB, Bogor, 1978.

Sidu Wasistiono, Kapita Selekta Pemerintahan Daerah, Fokusmedia, Bandung, 2003

Sonny Keraf, Etika Lingkungan, Buku Kompas, Jakarta, 2002

Satjipto Rahardjo, Membedah Hukum Progresif, Editor Joni Emorzon et al, Buku Kompas, Jakarta, 2006

Usman R, Pokok Pokok Hukum Alam Sekitar Nasional, Akademika Presindo, Jakarta, 1993

WALHI, Laporan Kegitan WALHI Tahun 1995-2000, 20021

Samodra Wibowo, Reformasi Administrasi, Bunga Rampai Pemikiran Administrasi Negara/Publik, Gava Media, Jogjakarta, 2006.

\section{CURICULUM VITAE}

Yasminingrum, SH MHum, adalah staf pengajar Fakultas Hukum UNTAG Semarang. Menamatkan S1 di FH UNTAG Semarang tahun 1996 dan S2 Ilmu Hukum di UNDIP Semarang tahun 1997. Jabatan yang pernah dipegang adalah Sekjur HAN mulai Tahun 1999-2002 dan menjabat Kabag HAN tahun 2002 sampai tahun 2010. Dan sejak tahun 2010 menjabat sebagai Ketua
Laboratorium. Mata kuliah yang diampu adalah HAN, Hukum Lingkungan, Kapita Selekta HAN, Ilmu Negara. Disamping mengajar di Fakultas Hukum UNTAG Semarang, juga mengajar di Fakultas Ekonomi Prodi Akuntansi mata kuliah HAN, dan sebagai pengajar Program S2 Ilmu Hukum Fakultas Hukum UNTAG Semarang, mata kuliah HAN dan Aparatur Negara \& Birokrasi Publik Pernah mengajar Filsafat pancasila di STIH Palangkaraya Tahun 1988, dan Pendidikan Kewarganegaraan di FE UDINUS Semarang Tahun 2003. Menduduki Bendahara Asosiasi HTN-HAN Komda Jawa Tengah Tahun 2002-2007, Kepala devisi hukum dan kebijakan publik LP3D Jawa Tengah, dan wakil Ketua Lembaga Pengkajian Penelitian dan Pengembangan Potensi masyarakat.

Hasil karya dalam bentuk buku adalah Pengantar Hukum Administrasi Negara (bersama Edi Pranoto, SH MHum), Hukum Lingkungan, Ilmu Negara, Kapita Selekta Hukum Administrasi Negara, Hukum Pajak, Hukum Kehutanan. 